\title{
The African Adoption of the Portuguese Crusade during the Fifteenth and Sixteenth Centuries
}

\author{
Adam Simmons \\ Department of History, Languages, and Global Cultures, Nottingham Trent University, \\ Nottingham, UK \\ Email: adam.simmons@ntu.ac.uk
}

\begin{abstract}
The Portuguese engagement with the continent of Africa following the conquest of Ceuta in 1415 was framed, among numerous conditions, as a crusade (Portuguese: cruzada). However, crusading influences on Portuguese expansion are often sidelined in favour of economic motives. Unlike North and north-east Africa's connected histories with the Crusades (1095-1291) and the continual role of crusading in the following centuries, the fifteenth century offered a new arena. Kongo's adoption of Christianity in the late fifteenth century was the first time that an African power can be viewed as engaging in crusading ideology as a Latin Christian power. Significantly, Kongo was converted by Portuguese missionaries who were undertaking their own crusade. Yet, the crusading influence on Kongo's early development of its Christianity has hitherto been overlooked in Africanist scholarship. Similarly, the situation in Kongo remains a lacuna in Crusades scholarship too. This article calls for a closer discussion between the histories of Africa and the Crusades through the case of Kongo and comparative African examples, such as Benin and Ndongo, to highlight the need to better connect these histories.
\end{abstract}

The Portuguese engagement with the continent of Africa following the conquest of Ceuta in 1415 was framed, among numerous conditions, as a crusade (Portuguese: cruzada). That is not to say that economic desires, such as obtaining slaves, gold, and ivory, were not important for the imperial intentions of the Portuguese, but that the undertones of a crusading zeal held by its kings had been prevalent since the heights of the Reconquista which paved the way for expanding Iberian expansion into Africa. ${ }^{1}$ Indeed, Luís Vaz de

\footnotetext{
${ }^{1}$ On pre-fifteenth-century crusading in Portugal, see R. da Costa, 'A mentalidade de cruzada em Portugal (séculos XII-XIV)', Anos 90, 16 (2001-2), pp. 143-78; K. Villads Jensen, Crusading at the edges of Europe: Denmark and Portugal c. 1000-c. 1250 (Abingdon, 2017).

(C) The Author(s), 2021. Published by Cambridge University Press. This is an Open Access article, distributed under the terms of the Creative Commons Attribution licence (http://creativecommons.org/licenses/by/4.0), which permits unrestricted reuse, distribution, and reproduction, provided the original article is properly cited.
} 
Camões's epic poem Os Lusiádas (first published in 1572) frames the endeavours of the Portuguese empire during the fifteenth and sixteenth centuries within the undertones of crusading. The second stanza of the first canto makes clear:

And, also, the glorious memory

Of those kings, who expanded

The Faith, [and] the Empire, [and who] went forth and

Laid waste to the accursed lands of Africa and of Asia. ${ }^{2}$

Later Portuguese imperialism may have mostly lost its specific characterization as a continual crusade, but the Portuguese mentality had not completely dissociated itself from that approach.

Defining what the Crusades were - and even how many there were - and what crusading encompassed has been notoriously problematic in scholarship, especially for events which happened following the fall of Acre, the last Latin Christian stronghold in the Holy Land, in $1291 .^{3}$ However, some common themes can be deduced which will help to frame the following discussion. The first is the importance of the papacy's leadership. The second is the papal awarding of indulgences to participants and acts of authorization through crusading bulls. The direct and indirect use and adoption of the crusading ideology discussed below should be viewed alongside other contemporary crusading arenas, such as in the Baltic. On the one hand, it is little different from how events elsewhere are currently framed as para-crusading, as many original crusading influences were omnipresent in early Afro-Portuguese relations. On the other, these engagements may be at best described as pseudocrusading - or not strictly crusading at all. ${ }^{4}$ Whatever the conclusion that may be reached, first and foremost Africa has an important place in the study of crusading and vice versa.

This article is not intended to evaluate Portuguese crusading motives per se. Instead, it seeks to situate the influence of crusading on African polities following their initial encounters with the Portuguese, and how they approached crusading ideology. For example, despite the conversion of the kingdom of Kongo and the attempted conversions of the kingdoms of Benin and Ndongo to Latin Christianity in the late fifteenth and early sixteenth centuries, it has never, to my knowledge, been asked if the ideology of crusading was taken up by Latin Christianity's new African converts. While the adoption of Latin Christianity was not consistent in west Central Africa, the innate role

\footnotetext{
${ }^{2}$ Luís Vaz de Camões, Os Lusiádas, ed. F. Pierce (Oxford, 1973), p. 7 (E também as memórias gloriosas / Daqueles Reis, que foram dilatando / A Fé, o Império, e as terras viciosas / De África e de Ásia andaram devastando). All translations in the article are my own.

${ }^{3}$ For overviews of this ongoing debate, see G. Constable, 'The historiography of the Crusades', in A. E. Laiou and R. P. Mottahedeh, eds., The Crusades from the perspective of Byzantium and the Muslim world (Washington, DC, 2001), pp. 1-22; N. Housley, Contesting the Crusades (Malden, MA, 2006), pp. 1-23; J. Riley-Smith, What were the Crusades? (Basingstoke, 2009); C. Tyerman, The debate on the Crusades, 1099-2010 (Manchester, 2011).

${ }^{4}$ On para- and pseudo-crusading, see Riley-Smith, What were the Crusades?, pp. 90-1.
} 
that crusading had in Latin Christian societies has not hitherto been explored for the African polities which adopted this same faith, notably in Kongo.

Similar to the crusading expansion into eastern Europe and the Baltic from the mid-twelfth century, fifteenth- and sixteenth-century Africa acts as a further example of what happened to crusading ideology upon the conversion of populations to Latin Christianity, together with all the auspices that its adoption could bring. Certainly, a brief review of relevant toponymy is suggestive of at least three stages of Portuguese crusading enterprise in Africa: Muslim North and West Africa, non-Muslim West and Central Africa, and Muslim East Africa. The exemplary toponyms in question are the modern Kikongo and Kiswahili toponyms for 'Portugal'. Mputu is how the Christian kingdom of Kongo viewed Portugal (Putu=Portugal). In stark contrast, Ureno - from the Portuguese reino ('kingdom') rather than its name - projects the Portuguese legacy as a crusading colonial power over the Muslim inhabitants of the Swahili coast; interestingly, this is not the case for later colonial powers such as the Netherlands (Uholanzi), England (Uingereza), or France (Ufaransa), at least in modern Kiswahili. Such historical linguistic traits may be taken as products of the differing relationship that crusading had on the two communities during the production of this toponymy. ${ }^{5}$ Taking these comparative toponyms as microcosms for Portuguese-African crusading relations, it is possible to investigate just how different the form of crusading was in Central Africa in the latter half of the fifteenth century and into the sixteenth century, in light of the lack of an established Muslim population, when compared with North Africa and the Swahili coast.

\section{I}

From the outset of Portuguese expansion in the early fifteenth century, North Africa remained a prominent arena for Portuguese crusading until a period of respite in the 1540s, when João III (r. 1521-57) withdrew from many North African strongholds to redirect finances elsewhere. This did not last long, however, as Sebastião (r. 1557-78), João's successor, returned attentions to North Africa during the following decades. ${ }^{6}$ The capture of Ceuta in 1415 has long been viewed as an extension of the Iberian crusading of the previous centuries, though crusading has not always been a key focus in the discussion of the Portuguese voyages beyond Muslim North Africa, with economic concerns being the most oft-repeated primary motive for Portuguese imperial

\footnotetext{
${ }^{5}$ Though we do have to be wary of historical changes in language. For example, as demonstrated by Koen Bostoen and Gilles-Maurice de Schryver, mapping modern Kikongo onto the pre-seventeenth-century kingdom of Kongo is not a matter of fact; see K. Bostoen and G.-M. de Schryver, 'Seventeenth-century Kikongo is not the ancestor of present-day Kikongo', in K. Bostoen and I. Brinkman, eds., The Kongo kingdom: the origins, dynamics and cosmopolitan culture of an African polity (Cambridge, 2018), pp. 60-102.

${ }^{6}$ See A. C. Hess, The forgotten frontier: a history of the of the sixteenth-century Ibero-African frontier (Chicago, IL, 1978).
} 
ambitions. ${ }^{7}$ Yet, Gomes Eanes de Zurara's five principal reasons behind Dom Henrique's (d. 1460) interest in West Africa were draped in crusading rhetoric, despite not using the word cruzada directly. According to Zurara, the royal chronicler of the early conquests up to 1448 , who completed his narrative in c. 1453, Dom Henrique's intentions were said to centre on: wanting to know what lands lay beyond Cape Bojador; a desire to seek and engage with Christian populations to trade; an intention to learn the geographical and political extent of Muslim North Africa; a hope to find Christian rulers who would join the fight against the Muslims; and the desire to spread the Christian faith throughout Africa. ${ }^{8}$ As Zurara's narrative is overtly encomiastic towards Henrique, it is clear that these crusading ideologies were integral for creating such public perceptions of the principal facilitator of early Portuguese expansion, whether they were his actual intentions or adopted by a persona. ${ }^{9}$

What is more, no fewer than sixty-nine papal bulls pertaining to Portuguese expansion were issued between 1415 and $1500 .^{10}$ Even if this may not have

\footnotetext{
${ }^{7}$ This is particularly clear in scholarship on the broader empire. For example, the following all either minimize the role of crusading for economic or strategic concerns - or, in the case of Russell-Wood, avoid any use of the word 'crusade' at all - or localize the role of crusading to North Africa: C. R. Boxer, The Portuguese seaborne empire, 1415-1825 (New York, NY, 1969), p. 18; B. W. Difffie and G. D. Winius, Foundations of the Portuguese empire, 1415-1580 (Minneapolis, MN, 1977); M. E. M. Santos, Viagens de exploração terrestre dos Portugueses em África (Voyages of terrestrial exploration of the Portuguese in Africa) (Lisbon, 1988); A. J. R. Russell-Wood, The Portuguese empire, 14151808: $a$ world on the move (Baltimore, MD, 1998); M. Newitt, A history of Portuguese overseas expansion, 1400-1668 (London, 2005), pp. 18-19; G. Marcocci, A consciência de um império. Portugal e o seu mundo (sécs. XV-XVII) (The conscience of an empire: Portugal and its world (fifteenth to seventeenth century)) (Coimbra, 2012), pp. 46-50. Similarly, Michał Tymowski has most recently re-emphasized the 'initial' nature of crusading influences behind the continual Afro-Portuguese encounters within West Africa, with the insinuation that this diminished as each decade passed: M. Tymowski, Europeans and Africans: mutual discoveries and first encounters (Leiden, 2020), p. 42. The economic focus by historians can particularly been seen in Vitorino Magalhães Godinho's collection of sources on Portuguese expansion, which also notably deliberately emphasizes the economic and political, rather than the crusading, motives found in Zurara: V. M. Godinho, Documentos sobre a expansão portusuesa (Documents on the Portuguese expansion) (3 vols., Lisbon, 1943-56), I, pp. 56-57.

${ }^{8}$ Gomes Eanes de Zurara, Crónica dos feitos notáveis que se passaram na conquista de Guiné por mandado do infante D. Henrique (Chronicle of the notable deeds that took place during the conquest of Guinea by order of the infante Dom Henrique), ed. T. de Sousa Soares (2 vols., Lisbon, 1978-81), I, ch. 7, pp. 43-5.

${ }^{9}$ On such issues, see L. de Albuquerque, 'Uma releitura da Azurara' ('A reinterpretation of Azurara'), Studia, 47 (1989), pp. 417-38; L. F. Barreto, 'Gomes Eanes de Zurara e o problema da "Cronica da Guine" ('Gomes Eanes de Zurara and the problem of the "Guinea chronicle"), Studia, 47 (1989), pp. 311-69; I. Elbl, 'Man of his time (and peers): a new look at Henry the Navigator', Luso-Brazilian Review, 28 (1991), pp. 73-89.

${ }^{10}$ C.-M. de Witte, 'Les Bulles pontificales et l'expansion portugaise au XVe siècle', Revue d'Histoire Ecclésiastique, 48 (1953), pp. 683-718; 49 (1954), pp. 438-61; 51 (1956), pp. 413-53, 809-56; 53 (1958), pp. 4-46, 440-71. On papal interest in Portuguese crusading during the century, see C.-M. de Witte, 'Les letters papales concernant l'expansion portugaise au XVIe siecle', Neue Zeitschrift für Missionswissenschaft, 40 (1984), pp. 1-25, 93-125, 194-205; 41 (1985), pp. 41-68, 118-37, 173-87, 271-87; L. Adão De Fonseca, M. C. Pimenta, and P. Pinto Costa, 'The papacy and the crusade in XVth century Portugal', in M. Balard, ed., La papauté et les croisades. Actes du VIIe congrès de la Society for the Study of the Crusades and the Latin East/The papacy and the Crusades: proceedings of the VIIth conference of the Society for the Crusades and the Latin East (Farnham, 2011), pp. 141-56.
} 
been the lived experience of all the Portuguese and others on board their ships, Portuguese expansion was entwined early on with papal direction. Likewise, Portuguese military orders, most clearly exemplified by Dom Henrique's leadership as the Grand Master of the Order of Christ from 1420, played an important role in the kingdom's oceanic operations in the fifteenth and sixteenth centuries. ${ }^{11}$ Significantly, in 1454 , the year following the Ottoman conquest of Constantinople, Dom Afonso V bestowed upon the order the eternal oversight of all the spiritual affairs and jurisdiction over all the beaches, coasts, islands, and conquered, and yet-to-be-conquered, lands of 'Guinea', Nubia, and 'Ethiopia', including lands of Africa not yet named (e per quaesquer outros nomes que sejam chamadas). ${ }^{12}$ The crusading role of the order in Portuguese imperial ambitions based on its ability to wage war and spread the Christian faith was still perceived as a key component during negotiations between Pope Julius III and Dom João III concerning the order's restructure in the sixteenth century. ${ }^{13}$ As noted by Luís Adão De Fonseca, Maria Cristina Pimenta, and Paula Pinto Costa, the fact that the Portuguese monarchy and the Order of Christ were so closely entwined resulted in crusading being a central tenet of all Portuguese expansion regardless of other contributing factors. ${ }^{14}$ Furthermore, the symbol of the Order of Christ continued to appear over Portuguese African dominions on contemporary maps to emphasize their crusading conquests. ${ }^{15}$

Interestingly, this crusading leadership occasionally limited the availability of royal patronage. The contract awarded to Fernão Gomes in 1469 exemplified the royal prerogative towards North Africa, as Gomes became responsible for the conduct of trade beyond the coast opposite the Cape Verde Islands and, as a condition of his contract, also had to continually explore further along the African coastline each year while royal attentions were turned towards North Africa. ${ }^{16}$ Similarly, the Arguim trade was leased to others, with Gomes also acquiring this contract in return for Dom Afonso $\mathrm{V}$ receiving an annual fee, while trading along the coast opposite Cape Verde became the right of the recent settlers of the islands as a reward for their settlement. Somewhat ironically, Gomes's enterprising operations launched fleets of ships, rather than the individual voyages instigated under royal direction, and rapidly increased contacts for areas of commerce for the Portuguese. Within only a

\footnotetext{
${ }^{11}$ On this, see L. Adão da Fonseca, 'The Portuguese military orders and the oceanic navigations: from piracy to empire (fifteenth to early sixteenth centuries)', in J. Upton-Ward, ed., The military orders, vol. 4: on land and by sea (Aldershot, 2008), pp. 63-73.

${ }^{12}$ A. J. Dinis Dias, ed., Monumenta Henricina, vol. 12 (Coimbra, 1971), p. 5.

${ }^{13}$ On the wider process, see F. Olival, 'Structural changes within the 16th-century Portuguese military orders', E-Journal of Portuguese History, 2 (2004), pp. 1-20.

${ }^{14}$ Adão De Fonseca, Pimenta, and Pinto Costa, 'The papacy and the crusade', pp. 150-2.

${ }^{15} \mathrm{M}$. H. Voss, "In this sign you shall conquer": the cross of the Order of Christ in sixteenthcentury Portuguese cartography', Terrae Incognitae, 39 (2007), pp. 24-36.

${ }^{16}$ Ásia de Joam de Barros, dos fectos que os Portugueses fizeram no descobrimento et conquista dos mares et terras do Oriente (Asia by Joam de Barros, of the achievements that the Portuguese made in the discovery and conquest of the seas and lands of the East) (henceforth Barros, Da Ásia, década 1) (Lisbon, 1552), bk 2, ch. 2, pp. 22a-23b.
} 
few years, Gomes's ships had made initial contact with various African groups and had sighted the islands in the Gulf of Guinea: Bioko, São Tomé, and Príncipe.

It is therefore significant that, following the troubles of the 1470s - notably conflict with Castile, which caused Gomes to cancel his contract in 1475 - upon Dom João II's succession (nominally from 1477 but officially 1481-95), the king focused his efforts on recentralizing his power, and the monarchy once again led expansion first hand. The crusading influence was once again central to expansion and the papal indulgences which were awarded to any who helped to build and establish the fort of São Jorge da Mina from 1481 off the coast of modern Ghana - which were remarkably similar to the indulgences awarded to those in defence of the Holy Land in 1485 - should not be overshadowed by economic motives. ${ }^{17}$ Crusading rewards were needed to entice people to establish the new fort; potential economic rewards were not enough. Moreover, Portuguese expansion was led, and often dominated, by the nobility, the social group most closely associated historically with the role of crusading within society, in relation to their position both within the royal household and within military orders. Their participation thus ensured that crusading remained a key influence among those leading each phase of expansion. ${ }^{18}$

Crusading can be seen to be a key element of Portuguese expansion leading into Central Africa. Once the Cape of Good Hope was rounded in 1488, the series of primarily Muslim Swahili city states that the Portuguese encountered along the East African coast posed a new question for the Portuguese crusading endeavour not seen since the first voyages along the West African coast. Once again, the Portuguese engaged with Muslims, who still bore the focus of the crusading rhetoric of expansion. However, Jeremy Prestholdt has explicitly questioned the characterization of Portuguese-Swahili interaction as a continuation of crusading, unlike the events in North Africa. ${ }^{19}$ It is, perhaps, notable that supposed enemies of the crusading Portuguese equally did not necessarily view conflict as a continuation of the Crusades. For instance, the Ottoman admiral Pīri Reis wrote in his Kitāb-ı bahrìye (Book of the sea) in the early sixteenth century about how the Portuguese reached the Indian Ocean, but ended his discussion by stating that the reasons for Portuguese expansion were primarily influenced by access to trade.$^{20}$ As in West Africa and as will be shown for Central Africa, crusading is not suggested to be the primary motive of Portuguese expansion in East Africa and may well not best describe Portuguese-Swahili interaction in its totality. Nevertheless, it should not be

\footnotetext{
${ }^{17}$ J. M. da Silva Marques, Descobrimentos Portugueses (Portuguese discoveries) (5 vols., Lisbon, 1988), III, pp. 242-3, 285-9.

${ }^{18}$ M. Małowist, 'Les aspects sociaux de la première phase de l'expansion coloniale', Africana Bulletin, 1 (1964), pp. 11-40; Adão da Fonseca, 'Portuguese military orders'. For the continued importance of the military orders for the Portuguese nobility in general, see F. Olival, 'The military orders and the nobility in Portugal, 1500-1800', Mediterranean Studies, 11 (2002), pp. 71-88.

${ }^{19} \mathrm{~J}$. Prestholdt, "Portuguese conceptual categories and the "other" encounter on the Swahili Coast', in M. Keita, ed., Conceptualizing/re-conceptualizing Africa: the construction of Africa historical identity (Leiden, 2002), pp. 53-76, at p. 56.

${ }^{20}$ Pīrī Reis, Kitāb-ı Bahrìye (Book of the sea), ed. E. Z. Ökte et al. (4 vols., Ankara, 1988), I, pp. 119-35.
} 
minimized, especially in light of the following discussion of the implementation of crusading by Central African rulers themselves. In terms of the Swahili coast, crusading certainly remained present in Portuguese operations, in terms both of fulfilling a cruzada and of the regional focus on finding Prester John.

While the search for Prester John in East Africa is not directly connected to crusading ideology, a brief discussion here will serve to highlight the importance of myths which had developed throughout the crusading era in relation to contemporary Portuguese expansion. Once the rulers of Central Africa had been understood to not be Prester John (and in some cases even in parallel, as soon as the Portuguese rounded the Cape of Good Hope), enquiries were made for the Prester's location. For example, his whereabouts were raised by those who arrived in Sofala in $1502 .{ }^{21}$ Equally, Sofala was described as having a Christian king who was subject to Prester John by Leonardo da Ca' Masser in c. $1505 .^{22}$ Indeed, until the Portuguese reached Ethiopia, the search for Prester John across Africa remained an important factor in their endeavours. ${ }^{23}$ In addition to investigating the conflated power of Prester John, individuals were instructed to undertake and maintain the cruzada. For instance, in the regimento issued to Francisco de Almeida in 1505 regarding his East African exploits, allusions to crusading motives appear-though without actually using the word cruzada. His instructions clearly state that it is resident Moors, rather than the local African merchants, who should be made captive, and their property seized, because they 'are enemies of our holy Catholic faith and because we wage war continually against them' (serem imiguos de nosa samta fee catholica e com eles teermos contynuadamenta guerra). In contrast, the African merchants should be treated well, 'as though they were our own and that we shall ever hold them in that esteem' (asy como cousas nossas propias em cujo lugar sempre os aveemos de teer). ${ }^{24}$

Not all supported the continuation of crusading fervour in the Indian Ocean, however. For example, concern regarding the focus of crusading can be found in two letters by the feitor (factor) of Moçambique, Diogo Vaz, in 1509 , denouncing the actions of Duarte de Lemos, who was deemed to be abusing the authority bestowed on him by the king in the region. Vaz decried the fact that people believed that there were Turks (Rumes) in East Africa who wished to make war on the king when this was not the case. Instead, the Portuguese should be called the Rumes as they should be called destroyers (danadores) and robbers (roubadores), rather than conquistadores, as it was they who had brought about the destruction of the empire, not any particular

\footnotetext{
${ }^{21}$ The land of the Paepians was a Dutch corruption of the land of Prester John: see J. P. Berjeau, ed. and trans., Calcoen: a Dutch narrative of the second voyage of Vasco da Gama to Calicut [1504] (London, 1874), p. 18.

22 'Relazione di Leonardo da Ca' Masser alla Serenissima Repubblica di Venezia sopra il commercio dei Portoghesi nell' India dopo la scoperta del Capo di Buona Speranza (1497-1506)', in Archivio storico Italiano. Appendice, vol. 2 (Florence, 1845), p. 25.

${ }^{23}$ A. Knobler, Mythology and diplomacy in the age of exploration (Leiden, 2017), pp. 43-9.

${ }^{24}$ Documentos dos Portugueses em Moçambique e na África Central, 1497-1840 (Documents of the Portuguese in Mozambique and Central Africa, 1497-1840) (9 vols., Lisbon, 1962-89), I, p. 180.
} 
group of Muslims. ${ }^{25}$ While Vaz does not denounce the crusading ideology outright, he clearly viewed the almost cavalier crusading mentality of some as a hindrance to the survival of the Portuguese in East Africa, if the imperial cruzada continued to be fought recklessly, drawing out the Mediterranean and subsequent Atlantic sense of conflict.

Dom Manuel I (r. 1495-1521) has been characterized by Luís Filipe Thomaz as purposefully fostering ambiguity between the factions for crusade and those for economics in the decades following the opening of the route to India. ${ }^{26}$ That said, Damião de Góis's crónica devoted to Dom Manuel is limited in its crusading rhetoric when describing royal affairs in the early sixteenth century. One instance is revealing, however, as Manuel's embassy to Pope Julius II in 1505 was recorded as seeking to ask the pope's blessing for Manuel's perpetual administration of the Order of Christ, to request the award of a new crusade, and to obtain indulgences for the efforts made in North Africa. ${ }^{27}$ The separation of these three points - with the new crusade not necessarily viewed as connected to the indulgences for North Africa - could be construed as seeking a new crusade alongside the establishment of Francisco de Almeida as first governor and viceroy of Portuguese India in the same year.

Whatever the case, crusading was still relevant to the Portuguese imperial mentality, as echoed in Vaz de Camões's Os Lusiádas. Once the Portuguese encountered the Ottomans in the western Indian Ocean and Red Sea, the enemy in the Mediterranean became an opponent to expansion. The crusading arena against the Ottomans was shared on both sides of Africa. Furthermore, although the expansion of crusading rhetoric and ideology into Asia is beyond the scope of this article, the renewing of the crusading element in Portuguese expansion continued across the Indian Ocean, building upon events in Africa. While the realpolitik of interactions with the Swahili coast did not act as an outlet for the cradling of the adoption of crusading ideology in East Africa by regional African rulers who were similarly targets for Latin Christian conversion, crusading took on a new form in west Central Africa.

Now that we have outlined the role of crusading rhetoric and ideology in the periods of Portuguese expansion before and after the opening of the Central African Atlantic, we can focus on the region at the centre of this article. Unlike other African regions, Central Africa was unique for its absence of Muslims. Thus, the Portuguese were able to build upon what was perceived to be a blank canvas in comparison to previous conversion efforts elsewhere, rather than framing the situation as a competition against Islam. However, this often led to the fusion of elements of Christianity with local beliefs and

\footnotetext{
${ }^{25}$ Ibid., II, pp. 378-84.

${ }^{26}$ L. F. F. R. Thomaz, 'Factions, interests and messianism: the politics of Portuguese expansion in the east, 1500-1521', Indian Economic and Social History Review, 28 (1991), pp. 97-109.

${ }^{27}$ Damião de Góis, Chronica do felicissimo rei Dom Emanuel (Chronicle of the most blessed king Dom Emanuel) (Lisbon, 2010), first part, ch. 93, p. 169.
} 
practices - described as Afro-Christian syncretism in the case of Kongo by John Thornton. ${ }^{28}$ This Africanized Latin Christianity was not the ideal method by which the Portuguese wished to bring Christianity to the region but, without this evolution, Christianity remained peripheral, as happened in Ndongo. Discussion here will focus on the three polities of Kongo, Ndongo, and Benin, each of which reveal a myriad of ways that crusading ideology could be either adopted or rejected by African rulers. Scholarly discussion surrounding the Central African appropriation of European Latin Christian culture has focused on the many elements which were adopted, yet crusading ideology has hitherto evaded inclusion in such analysis. ${ }^{29}$

The geographies and politics of Kongo, Ndongo, and Benin offer case studies situated throughout west Central Africa. Respective long reigns in each kingdom also created conditions which provided a singular authority to mould relations with the Portuguese over the initial decades, thus enabling politically strong African rulers to decide for themselves whether to accept or reject crusading, or even Latin Christian rhetoric or ideology in general. Upon the Portuguese's arrival in these polities, they liaised with very few internal rulers for many generations. For example, in Benin, there were only three obas over the course of a century: Ozolua (r. c. 1481-1516), Esigie (r. c. 1516-50), and Orhogbua (r. 1550-78), with long reigns being the norm until the late seventeenth century. In Kongo mwenekongos Nzinga a Nkuwu (r. c. 1470-1509) and Mvemba a Nzinga (r. 1509-1542) ruled until the more turbulent times of the mid-sixteenth century. Likewise, in Ndongo Ngola Kiluanje kia Samba (r. c. 1515-56) provided long-term stability until the short turbulent reign of Ndambi a Ngola (r. 1556-61). Long reigns do not necessarily reflect strength or even an absence of turbulent conflict, as was the case in Benin, but it is notable that none of the three African polities suffered from quick successions of rulers or particularly damaging internal politics which the Portuguese may have been able to benefit from until the mid-sixteenth century. The adoption and rejection of crusading ideology was very much an African endeavour, which makes these case studies so intriguing for reflection on how each dealt with the arrival of Latin Christianity and all of its auspices.

The largest arena by far for the use and adoption of crusading rhetoric and ideology within Africa was in Kongo. From the outset, Kongolese-Portuguese relations were tightly interwoven, seemingly much more so than other comparatively early encounters between the Portuguese and African polities or groups. Kongo first encountered the Portuguese in 1483, and within a year the Kongolese prince Kala ka Mfusu, known in Europe as Dom João da Silva, voyaged to Portugal. Kala ka Mfusu returned to Kongo in 1485 and led an official delegation back to Portugal between 1488 and $1490 .^{30}$ The return of this

\footnotetext{
${ }^{28}$ For Kongo, see J. K. Thornton, 'Afro-Christian syncretism in the kingdom of Kongo', Journal of African History, 54 (2013), pp. 53-77.

${ }^{29}$ Most explicitly, see L. Heywood and J. K. Thornton, 'Central African leadership and the appropriation of European culture', in P. C. Mancall, ed., The Atlantic world and Virginia, 1550-1624 (Chapel Hill, NC, 2007), pp. 194-224.

${ }^{30}$ G. de Resende, Chronica de el-rei D. João II (Chronicle of the king Dom João II) (3 vols., Lisbon, 1902), II, ch. 156, pp. 153-7; Rui de Pina, 'Chrónica d'el Rei Dom João II' ('Chronicle of the king Dom João II'), in
} 
delegation in 1490 provides the first reference to crusading influences during early Kongolese-Portuguese relations. According to João de Barros writing in the mid-sixteenth century, the delegation arrived with a crusading banner (hũa bandeira com hũa Cruz) for the mwenekongo of Kongo from Dom João II, which had been given to him by Pope Innocent VIII. Kongo was literally to fly the banner of crusading. Importantly for the mwenekongo, the adoption of crusading ideology via the carrying of the cross-inscribed banner promised him victory over his enemies, whom he was about to depart to fight. ${ }^{31}$ In the following year, the Kongolese ruler, Nzinga a Nkuwu, was baptized and became known as João I of Kongo, imitating his namesake in Portugal. However, his personal devotion to Christianity was short-lived. Nevertheless, in 1493 Dom Pedro, another royal relative, journeyed to Portugal. He was later joined by Dom Henrique, son of the next mwenekongo, Mvemba a Nzinga, who became the first ordained Kongolese bishop.

The early foundations of the Kongolese church were steeped in crusading motifs, though these have not received much attention in relation to their potential influence on Kongolese Christianity. For instance, the prevalence of the cross in Kongolese culture has not been connected to a wider adoption of crusading ideology, though it has been noticed that there appears to have been an overall absence of Jerusalem in Kongolese Christian culture, which, given the crusading undertones of early Kongolese relations with Christianity presented here, is especially surprising. ${ }^{32}$ That said, a river and gulf of Nazareth, the modern Ogooué, is depicted to the north of Kongo by early European cartographers, which would suggest, in addition to the depictions of a cape and river of Saint Catherine in Gabon, that Holy Land sites were not too distant from the ideology of the European missionaries in the region during their engagement with Kongo. Indeed, in the early eighteenth century, the Kongolese prophetess Beatriz Kimpa Vita, in her mission to further 'Africanize' Kongolese Christianity, was recalled by the Capuchin missionary Bernardo da Gallo as having stated that Jesus Christ had been born in São Salvador (Mbanza Kongo), which was Bethlehem, and had been baptized in (Mbanza) Nsundi, which was Nazareth. ${ }^{33}$ Despite the lack of earlier evidence,

J. Correa da Serra, ed., Collecção de livros ineditos da historia portuguesa dos reinados de D. Joaõ I, D. Duarte, D. Affonso V, e D. João II (Collection of the unpublished books of Portuguese history from the reigns of Dom João I, Dom Duarte, Dom Affonso V, and Dom João II), vol. 2 (Lisbon, 1792), ch. 58, pp. 150-2.

${ }^{31}$ Barros, Da Ásia, década 1, bk 3 ch. 9, p. 35a. See also De Pina, 'Chrónica d'el Rei Dom João II', ch. 63, p. 172.

${ }^{32}$ For example, see J. K. Thornton, 'The development of an African Catholic Church in the kingdom of Kongo, 1491-1750', Journal of African History, 25 (1984), pp. 147-67; C. Fromont, The art of conversion: Christian visual culture in the kingdom of Kongo (Chapel Hill, NC, 2014). That said, the titular patriarch of Jerusalem was still deemed to be an important contact. For example, Álvaro II wrote to Patriarch Fabio Biondi in 1602 following the death of the first bishop of Angola and Kongo, Miguel Rangel, who had been consecrated by Biondi, regarding the vacant position; this correspondence may have reflected Biondi's previous ties to Lisbon rather than his current position, however: A. Brásio, ed., Monumenta missionaria Africana, 1st ser. (henceforth MMA) (15 vols., Lisbon, 195288), V. pp. 41-3.

${ }^{33}$ T. Filesi, 'Nazionalismo e religione nel Congo all'inizio del 1700', Africa, 26 (1971), pp. 463-508, at p. 496. 
a Kongolese disregard for the Holy Land sites as Christianity prospered would have been unlikely.

The long reign of Mvemba a Nzinga (known by his baptismal name Afonso I; r. 1506-43) should also not be overlooked for its significance in establishing crusading ideology in Kongo, especially as, unlike his father, he did not waver from Christianity. As Sébastien Meno Kikokula has highlighted, Afonso took Christian learning very seriously and established Kongo as a Christian cultural and intellectual centre. ${ }^{34}$ While it can only be surmised, his devotion to Christian learning was unlikely to have avoided the key facet of Portuguese Christianity - the ideology of crusading. Indeed, Afonso was even praised by Rui d'Aguiar, a Portuguese priest who was resident in Kongo, in a letter to Dom Manuel in 1516 for knowing more about elements of Christianity than even the Portuguese, and that he even taught them about the faith, so great was his knowledge. ${ }^{35}$

In 1512, Afonso received a regimento delivered by Simão da Silva from Dom Manuel which explained the structure of Portuguese society and administration for him to copy within Kongo. ${ }^{36}$ Afonso himself noted the Portuguese foundations of the Christian image that he was developing for his kingdom. ${ }^{37}$ The regimento did not discuss any role that crusading ideology had within the echelons of Portuguese society but it may be presumed that such information accompanied the regimento and other informative communications, such as regarding the crusading ideologies associated with the nobility. For example, it may have been that the later Kongolese development of their own Order of Christ, akin to the Portuguese military order, stemmed from such accompanying unwritten instruction. ${ }^{38}$ Similarly, according to an Italian copy of a letter from Dom Álvaro III of Kongo to his ambassador in Rome in 1619, this letter related how his confessor, Bras Correia-a man of Portuguese origin but one who had been raised in Kongo since his childhood - was the commissioner (commissario) of the Santa Cruzada in the kingdom. ${ }^{39}$ Given the evidence for Kongolese engagement with crusading throughout the sixteenth century, it may be considered likely that earlier commissioners, or those holding roles similar in nature, may have existed in earlier decades, possibly as early as the instructions to Afonso, though the office did not feature in the 1512 regimento. None of Afonso's letters to the kings of Portugal which survive use the word cruzada, nor do any contemporary external sources view Afonso as ever being explicitly on 'crusade'. Yet, a case can be made for incorporating Kongo into discussions of contemporary crusading.

Crusading ideology was prevalent during Afonso's reign. He reported a miracle in a letter of 1509 about how a cross and Santiago (St James) had appeared in the sky before a battle with his pagan brother for the right to be

\footnotetext{
${ }^{34}$ S. Meno Kikokula, 'La politique intellectuelle de Mvemba N'zinga (Dom Afonso Ier) Mani Kongo, 1506-1543', Annales Aequatoria, 23 (2002), pp. 197-216.

${ }^{35}$ MMA, I, pp. 361-3.

${ }^{36}$ Ibid., pp. 228-46.

${ }^{37}$ Ibid., pp. 258-9.

${ }^{38}$ A. L'Hoist, 'L'ordre du Christ au Congo', Revue de l'Aucam, 7 (1932), pp. 258-66.

${ }^{39}$ MMA, VI, p. 394.
} 
mwenekongo. A copy of this letter has not survived but Afonso again recalled details of this event in another letter of $1514 .^{40}$ The original 1509 letter, however, was likely used to inform Portuguese sources of the miracle. ${ }^{41}$ The appearance of a cross is reminiscent of crusade narratives and is highly suggestive of Afonso's crusading education, whether that was received directly or indirectly. ${ }^{42}$ Santiago had long been seen as a crusading military saint and his adoption also served to emphasize Kongo's Iberian Christian connections. ${ }^{43}$ Moreover, the adoption of Santiago is especially significant as he was long known as the Matamoros or 'Moor slayer'; Afonso was similarly vanquishing heathens. For a relative newcomer to Christianity, Afonso was seemingly well versed in Christian textual and ideological traditions pertaining to crusading. The history of the miraculous in crusading discourse had long been used as evidence for divine favour, and Afonso's adoption of this ideology likely served to cement his position following the defeat of his rival brother in battle prior to his succession. ${ }^{44}$ It is notable that early Kongolese supporters of Christianity, who mostly came from the elite of society, actively included crusading discourse in their shaping of what was an otherwise largely indigenous mould. After all, what better way was there to justify one's unquestionable right to rule than by divine favour in the form of miraculous apparitions?

Certainly, adopting elements of crusading discourse benefited Afonso's wider political and military strategy. The lack of evidence for any specific instance of a Kongolese uptake of a crusade in a military capacity likely points to the adoption of crusading as a political tool, rather than as a military construct. That said, the many wars fought by Afonso especially, which simultaneously increased the presence of slaves within the kingdom, should not necessarily be viewed in the absence of his acquired crusading fervour to justify his expansions. Later Portuguese commentators certainly claimed that the principal motive for Afonso's wars was to quell 'defiance against the faith' (rebeldia a Fé) by 'rebellious vassals' (vassallos rebelados), which may cast his wars in a crusading light, albeit without direct contemporary affirmation. ${ }^{45}$

\footnotetext{
${ }^{40}$ Ibid., I, pp. 294-5. Equally, Afonso recalled aspects of the event in letters to his lords and other subjects in 1512: ibid., I, pp. 257-9, and XV, p. 24.

${ }^{41}$ M. Fernandez de Enciso, Suma de geographia (Compendium of geography) (Seville, 1519), pp. 113-14; Barros, Da Ásia, década 1, bk 3 ch. 10, pp. 35b-36b.

${ }^{42}$ For some examples, see G. Constable, Crusaders and crusading in the twelfth century (Farnham, 2008), pp. 84-5. See also E. Lapina, 'Crusades, memory and visual culture: representations of the miracle of intervention of saints in battle', in M. Cassidy-Welch, ed., Remembering the Crusades and crusading (Abingdon, 2017), pp. 49-72.

${ }^{43}$ See J. van Herwaarden, 'The Spanish cult of St James and Islam: legends as history', in J. van Herwaarden, ed., Between Saint James and Erasmus: studies in late-medieval religious life: devotion and pilgrimage in the Netherlands (Leiden, 2003), pp. 451-91, at pp. 463-5.

${ }^{44}$ On the role of miracles in earlier crusade narratives, see B. C. Spacey, The miraculous and the writing of crusade narrative (Woodbridge, 2020). On Afonso's succession, see J. K. Thornton, A history of west Central Africa to 1850 (Cambridge, 2020), pp. 39-41.

${ }^{45}$ F. de Santa Maria, O ceo aberto na terra (Heaven opened on earth) (Lisbon, 1697), p. 897. On Afonso's wars, see Thornton, History of west Central Africa, pp. 42-3.
} 
Nevertheless, banners of Christ (bandeira[s] de Christus) certainly featured in the 1512 regimento received by Kongo for use in war. ${ }^{46}$

Additionally, Afonso found it imperative to create his own coat of arms upon his victory over his brother, which was depicted in António Godinho's armorial produced between c. 1521 and $1548 .{ }^{47}$ Afonso himself described the imagery of his chosen new heraldry in a letter to his lords in 1512, not long after his victory over his brother:

The red field signifies the great amount of blood that we spilt in the battle: the master in blue with the silver cross signifies the white cross that during the battle was seen in the blue sky: And the cross is flowered, representing the death of our enemies like that of the devil [in our land]: the scallops signify Santiago, whom we called, and the help he gave us: the shield of Portugal, which signifies that Portugal is the foundation of the faith we have with our Lord, where is our salvation. And the broken black idols on the same shield of Portugal signify that His will caused their breaking and their destruction: in the red-the five armoured arms, a sign of the armed men who were seen in the sky, our help, who were angels. And so they are to honour the five wounds of Our Lord Jesus Christ, who saved us. ${ }^{48}$

Taken within a crusading context, it is significant that Afonso's coat of arms places the white cross of his vision at the top of the shield, two sets of scallops to represent Santiago, and five armoured arms of knights, all of which can be seen to echo the Portuguese crusading influences on early Kongolese Christianity in all but name. Moreover, as pointed out by Cécile Fromont, Afonso's choice of imagery was ultimately directly influenced by Afonso Henriques's victory over the Almoravids in 1139 at Ourique, following a similar apparition of the cross and Santiago. ${ }^{49}$ Equally, Kongo's Christian foundations, which were predicated upon the image of the cross, shaped the invention of an ancestral affiliation with Portugal which, in turn, expressed a shared crusading heritage. ${ }^{50}$

\footnotetext{
${ }^{46}$ MMA, I, pp. 235-6.

${ }^{47}$ Arquivo Nacional da Torre do Tombo, Lisbon (ANTT), PT/TT/CR/D-A/001/20, fol. 7.

${ }^{48}$ MMA, I, pp. 258-9: 'O campo vermelho hé em significação do muyto samgue que em a batalha que ouvemos se espargeo: o chefe do escudo azul cõ a cruz de prata significa aquella cruz branca que naquella batalha foi vista no çeo, que hé azul: $\mathrm{E}$ a cruz florida, pello vençimẽto que se ouve assi contra os imiguos como contra o diabo: as vieyras, por ser devisa de Samtiaguo que ali chamamos e nos socorreo: hũ dos escudos de Portugal, em signal que Portugal hé fundamẽto da fee que temos com nosso Senhor, domde nos veo nossa saluação. $\mathrm{E}$ os dous Idolos negros quebrados açerca do dito escudo de Portugal, significa que elle foi causa de serem quebrados e destruidos: no vermelho - os cinco braços armados, em signal dos homẽs armados que no çeo foram vistos, em nossa ajuda, que eram anjos. E por isso estam em quina á homrra das çimco chaguas de nosso Senhor Jhesu Christo, cõ que nos salvou.'

${ }^{49}$ Fromont, Art of conversion, pp. 27-30.

${ }^{50}$ See M. de Lurdes Rosa, 'Velhos, novos e mutáveis sagrados ... um olhar antropológico sobre formas "religiosas" de percepção e interpretação da conquista africana (1415-1521)' ('The old,
} 
It should also be mentioned that no other heraldry of an African ruler was included in Godinho's armorial, including the historic fabled crusading ally of Latin Europe, Ethiopia. The crusading influences go further, with the possible reconstruction of Afonso's seal imitating the Constantinian motto In hoc signo vinces ('In this sign [the cross] you shall conquer'), which was simultaneously present on the coins of Dom Manuel I. ${ }^{51}$ Furthermore, while not explicit in their crusading vocabulary, Kongolese sangamentos performances reiterated, albeit indirectly, the crusading foundations of Afonso's Christian rule, such as memorializing his victory over his brother with the help of his vision of the cross and Santiago in battle..$^{52}$ They may not be as explicit in their message as the contemporaneous Los moros y cristianos ('Moors and Christians') dances in the Americas pertaining to Christian conquest, which were equally associated with Santiago Matamoros, but they certainly would have strengthened a Kongolese cultural identity that was underpinned by crusading ideology and motifs. ${ }^{53}$ Afonso's actions provided the blueprint for future Kongolese rulers who would need to find ways to gain political support, both internally and externally, via engagement with crusading discourse.

Indirectly related to Kongo's use of crusading ideology was its relationship with the papacy. Indulgences, for example, remained a key element of this relationship for both the papacy and the Kongolese rulers. For instance, the Kongolese embassy to Rome in 1535 sought to obtain all the 'graces, indulgences, liberties, and privileges' (graças, indullgemçias, liberdades e privylegios) bestowed on other Christian rulers by the pope for their king. ${ }^{54}$ Equally, in 1583 Dom Álvaro I of Kongo ordered Duarte Lopes to obtain an image of Our Lady directly copied from those painted by St Luke when he was to be received at the papal curia later in the decade, along with the indulgences attached to it. ${ }^{55}$ Similarly, Pope Clement VIII later invited another embassy from Kongo to Rome and sent a plenary indulgence, akin to those awarded to Crusaders for generations, to Dom Álvaro II in $1596 .^{56}$ It is likely that the first Kongolese embassy to Rome in 1513-14 similarly sought indulgences from Pope Leo X, though sources for this embassy are not overly forthcoming with specifics. ${ }^{57}$ The papacy held the authority to maintain Kongolese independence from the Portuguese and this was not lost on the rulers of Kongo and underpinned this ever-developing relationship, especially towards the

\footnotetext{
new and changing sacred ... an anthropological look at "religious" ways of perceiving and interpreting the African conquest (1415-1521)'), Lusitania Sacra, 2nd ser. 18 (2006), pp. 19-36.

${ }^{51}$ Fromont, Art of conversion, pp. 30-1.

${ }^{52}$ On these performances, see ibid., pp. 21-64.

${ }^{53}$ On the Los moros y cristianos dances, see M. Harris, Aztecs, Moors, and Christians: festivals of reconquest in Mexico and Spain (Austin, TX, 2000).

${ }^{54}$ MMA, II, p. 40.

${ }^{55}$ Ibid., III, p. 234.

${ }^{56}$ Ibid., IV, pp. 542-3, 544.

${ }^{57}$ See F. Bontinck, 'La premiere "ambassade” Congolaise a Rome (1514)', Etudes d'Histoire Africaine, 1 (1970), pp. 37-73; A. Brasio, 'Embaixador do Congo a Roma em 1514' ('Ambassador from Kongo to Rome in 1514'), Studia, 32 (1971), pp. 51-79; S. Meno Kikokula, 'Autour de l'ambassade de Mbanza Kongo 1514', Annales Aequatoria, 18 (1997), pp. 471-88.
} 
end of the sixteenth century. ${ }^{58}$ Moreover, such relations can be viewed amid papal intentions to 'globalize' their crusading endeavours following developments of the fifteenth century to cement papal universal authority. ${ }^{59}$ The fact that elements of crusading rhetoric continued to be used in these relations, whether purposefully or not, serves to emphasize not only Kongo's crusading origins but also their place within an active crusading Catholic sphere.

Despite the internalization of crusading ideology in Kongo, it was not a marker of Portuguese cultural domination, and Kongolese crusading rhetoric and ideology should be viewed independently. No event more starkly portrays this than the recorded battle cries of the Kongolese and Portuguese soldiers facing off at the battle of Mbumbi in 1622. Tensions between Kongo and Portugal had been increasing in the preceding decades, especially since the establishment of Portuguese Luanda in 1575 to the south of Kongo. The strength of Kongolese-papal relations proved a key factor in Kongo's diversion away from the Portuguese sphere. Before the battle, both sides invoked Santiago, but in clearly different embodiments. It was reported that the Kongolese soldiers said that, if the Portuguese's Santiago was white, then theirs was black. ${ }^{60}$ No African ethnicity was given to the Santiago who had first appeared to Afonso a century before. This example emphasizes how the original Portuguese crusading ideal had been adopted and fully developed by the Kongolese from its initial incarnations. While the continued invocation of Santiago in itself is not necessarily directly attributed to a continued crusading cause, it serves to highlight the longevity of the influence of the early relations which were framed, among many other things, by performing the continual cruzada.

The case of Ndongo offers an interesting extension to events in Kongo, producing quite different results. Ndongo was a vassal state of Kongo to its south. During the long reign of its ruler Ngola Kiluanje (r. c. 1515-56), Ndongo was able to reject initial Portuguese, as well as continuing Kongolese, advances. Little is known about the kingdom until the latter decades of the sixteenth century, but it does appear to have increased in its independence from Kongo from the early decades of the century, despite continuing Kongolese claims to the region. ${ }^{61}$ While no essence of crusading directly features in the

\footnotetext{
${ }^{58}$ For a synthesis of Kongolese-papal relations throughout this period, see T. Filesi, 'Le relazioni tra il regno del Congo e la sede apostolica nella prima metà del XV secolo', Africa, 22 (1967), pp. 247-85; T. Filesi, 'Le relazioni tra il regno del Congo e la sede apostolica nel XVI secolo', Africa, 22 (1967), pp. 413-60. Indeed, Kongo remained steadfastly loyal to the Roman Catholic Church despite the temptation to establish its own church in light of increasing Portuguese aggression; see, for example, J. K. Thornton, 'The kingdom of Kongo and the Counter Reformation', Social Sciences and Missions, 26 (2013), pp. 40-58.

${ }^{59}$ For example, see B. Weber, 'Toward a global crusade? The papacy and the non-Latin world in the fifteenth century', in N. Housley, Reconfiguring the fifteenth-century Crusade (London, 2017), pp. 11-44.

${ }^{60}$ A. de Oliveira de Cadornega, História geral das guerras angolanas (General history of the Angolan wars), ed. J. Matias Delgado and M. Alves da Cunha (3 vols., Lisbon, 1972), I, p. 105.

${ }^{61}$ For example, Amgolla is listed as being under the dominion of the mwenekongo in 1535: MMA, II, p. 38.
} 
regimento given to Manuel Pacheco and Baltasar de Castro to govern relations with the ngola of Ndongo - whom the Portuguese called Angola - in 1520, the primary objective was to convert the king and his kingdom, and any other local rulers, to Christianity. The regimento included directions to learn of sources for silver, along with ivory and slaves, but the fundamental objective was the spreading of Christianity. Most pertinently, it explicitly ordered that they should follow the example of how this had happened in Kongo (como hé elRey de Comguo). ${ }^{62}$ By extension, it may be presumed that the Portuguese expected similar crusader ideology to be adopted by the ngola of Ndongo, or any lesser rulers encountered, alongside their adoption of Christianity.

Unlike in Kongo, however, interest in Christianity in Ndongo remained largely elusive and separate from desires to enhance economic wealth via trade with the Portuguese until the $1570 \mathrm{~s}^{63}$ The failure of the 1520 mission is highlighted in a letter from Frei Gouveia in 1563 in relation to the embassy which had set out for Ndongo from Lisbon in 1559. Gouveia implored Dom Sebastião of Portugal that Ndongo needed to be conquered in order to convert its people in earnest, otherwise conversion could not be truly realized, further giving the example of Kongo's perceived failure to maintain 'true' Christianity. ${ }^{64}$ It may even be said that, without using the exact terminology, Gouveia was essentially calling for the cruzada to be directed towards Ndongo to establish Christianity. Certainly, bulls of crusade were issued in support of the Portuguese efforts in Angola into the seventeenth century. ${ }^{65}$ Clearly, the ngola did not view the adoption of any remnants of crusading rhetoric or ideology as being beneficial, as the mwenekongo of Kongo had done, despite the Kongolese origins of Ndongo. Instead, the inhabitants of Ndongo became victims of the cruzada, rather than embracers of it.

In sharp contrast to Kongo, very different events occurred in Benin, despite potentially similar interests held by its rulers for the adoption of crusading rhetoric and ideology. According to António Galvão, writing in the midsixteenth century, Ruy de Siqueira was the first Portuguese to reach Benin, in $1472 .{ }^{66}$ However, no meaningful documented contact survives before 1485 . Even following 1485, the feitoria (trading post) that was established by the Portuguese in Gwato, 'the port of Benin', was inconsistently occupied until it was closed in 1506-7, and appears to have been vacant for a period during the second half of the $1490 \mathrm{~s}^{67}$ The early Portuguese focus was primarily towards trade, with no missionaries appearing during the initial contacts, though João II did send 'holy and most Catholic admonitions' (sanctos e muy Catolicos conselhos) to the oba. ${ }^{68}$

\footnotetext{
${ }^{62}$ MMA, I, pp. 431-40, at pp. 431-2.

${ }^{63}$ L. M. Heywood and J. K. Thornton, Central Africans, Atlantic creoles, and the foundation of the Americas, 1585-1660 (Cambridge, 2007), pp. 79-82.

${ }^{64}$ MMA, II, p. 528.

${ }^{65}$ For example, ibid., VI, pp. 143, 151-2, and VII, pp. 121-3.

${ }^{66}$ António Galvão, Tratado dos descobrimentos (Treatise on the discoveries) (Porto, 1944), p. 129.

${ }^{67}$ A. F. C. Ryder, Benin and the Europeans, 1485-1897 (London, 1969), pp. 32-3.

${ }^{68}$ De Pina, 'Chrónica d'el Rei Dom João II', ch. 24, pp. 74-5.
} 
Despite the lack of missionary engagement, hope had been building for a Christianized Benin as early as 1485, as João Afonso Aveira noted the existence of a ruler named Ogané who was treated like the Latin pope by the Africans of west Central Africa. ${ }^{69}$ In fact, this was the ọọni of Ifè̀, who held a role of spiritual significance for local populations, including the Bini of Benin, and who consecrated each new oba. Such a regional influential figure naturally inspired Portuguese beliefs of locating Prester John. This belief was only fuelled by the emblem of the cross being prominent in Bini culture - for example, worn on necklaces by ọbas, which were gifts by the ọoni upon each oba's coronation, and court officials alike - further inspiring the Portuguese..$^{70}$ oba Ozolua, the ruler of Benin, was even said to have sanctioned a church to be built there following the arrival of the Portuguese. ${ }^{71}$ In truth, Ozolua remained indifferent to the Portuguese's initial appearance, most likely due to the severe internal struggles and battles during his reign focusing his attentions elsewhere. ${ }^{72}$ Ozolua's outlook was also the result of the lack of utility that he saw in the goods offered for trade by the Portuguese, which had no ability to influence the oba's continual conflicts, particularly as there was no trade in arms. ${ }^{73}$ Nevertheless, regardless of the inconsistent permanent Portuguese trade presence within Benin, Ozolua sent eight slaves as gifts to prominent figures at São Jorge da Mina (five to capitão (captain) Fernão Lopes Correa and three to feitor Gil Matoso) in the second half of the 1490s, suggesting that his indifference was not always necessarily dismissive of the Portuguese during the first two decades of contact. ${ }^{74}$

Following the first Benin embassy to Portugal in 1486, three more were sent in 1514,1516 , and 1540 , but sustained close ties remained elusive. This outlook had changed slightly by 1514 , as both the embassies of 1514 and 1516 centred on requesting Portuguese military assistance against the oba's enemies. That assistance was duly given. In c. 1516 Ozolua was killed in battle and was succeeded by his son, Oba Esigie (r. c. 1516-50), whose reign was once again characterized by conflict, according to local tradition. ${ }^{75}$ It was within this context that the earliest surviving document relating to crusading in Benin is known. Ozolua was said to have embraced Christianity in the final year of his life, following the Portuguese arrival in 1515 in response to the 1514 embassy, and he allowed churches to be built. ${ }^{76}$ Any evidence for Esigie's conversion during his father's final year is circumspect. Whatever the case, by August 1517, a bull of crusade was sent to Benin in the company of

\footnotetext{
${ }^{69}$ Barros, Da Ásia, década 1, bk 3, ch. 4, p. 28 a.

${ }^{70} \mathrm{Ibid}$. Such crosses can also be seen on contemporary statues of court officials, such as the sixteenth-/seventeenth-century brass statue of a male court official held at the Metropolitan Museum of Art in New York (acc. no. 1991.17.32); see K. Ezra, Royal art of Benin: the Perls collection in the Metropolitan Museum of Art (New York, NY, 1992), pp. 67-9, 72-3.

${ }^{71}$ MMA, I, pp. 369-70.

${ }^{72} \mathrm{~K} . \mathrm{W}$. Gunsch, The Benin plaques: a 16th century imperial monument (Abingdon, 2018), pp. 29-33.

${ }^{73}$ Ryder, Benin and the Europeans, p. 41.

${ }^{74}$ ANTT, Núcleo antigo, maço 186, fols. 3r, 14v.

${ }^{75}$ Gunsch, Benin plaques, pp. 33-6.

${ }^{76}$ Ryder, Benin and the Europeans, pp. 46-50.
} 
Diogo Belo and three other priests via São Tomé, who intended to convert the new oba, possibly inspired by the situation in Kongo and its embracing of Christianity in similar times of conflict, and not least encouraged by a letter from Duarte Pires to Dom Manuel in the previous year which painted the oba as a willing recipient of Christianity and one who had opened his realm to the faith. ${ }^{77}$ In fact, Duarte Pires signed off his letter as being 'written during the war' (feita nesta guerra), indicating that the oba was primarily concerned with internal affairs and that the crusading ideology brought with the Portuguese was of no interest to the oba in itself.

In comparison to Kongo, it was Portuguese numbers, not potential divine apparitions, or other crusading ideology, which were viewed by the oba as being the most important factor to potentially aid in his kingdom's internal conflicts. Indeed, there is no evidence to indicate the oba's interest in a later failed mission initiated by the Portuguese, including two Franciscans and a member of the Order of Christ, in 1538. Additionally, the embassy sent by Oba Esigie to Portugal in 1540 has left little in the way of motives in the surviving sources, though the adoption of Christianity does not appear to have been its main concern, and the Portuguese soon abandoned all efforts to convert any oba of Benin for the foreseeable future. ${ }^{78}$ This scenario is notably different from events in Kongo and highlights how crusading ideologies could have been adopted for enhancing the power of both Ozolua and Esigie, but both opted not to explore the ideology and its auspices, as the mwenekongos had done, even though Portuguese contemporaries commented on the oba's political motivations for what they viewed as feigning insincere interest in Christianity, and this provides an interesting comparison for both African and crusading studies. ${ }^{79}$

One final question remains, and it is one which requires much more research than could be offered here: what of the role and presence of Africans within institutions whose entire existence was owed to crusading, notably the military orders? For example, following the expansion of crusading into Central Africa, there is limited evidence for Africans joining the Order of Santiago in the sixteenth century: Pedro de Sousa, cousin and ambassador of the mwenekongo to Portugal (initiated 1512, while in Portugal); Luís Peres (initiated 1550), a fidalgo (nobleman) of the mwenekongo; Dom Pedro da Silva (initiated 1579), cavaleiro fidalgo (knight nobleman) and ambassador of the ngola of Ndongo; and a João de Sá Panasco (initiated c. 1540s), of otherwise unknown origin, the former slave and court jester of Dom João III. ${ }^{80}$ Despite

\footnotetext{
${ }^{77}$ MMA, I, pp. 412-13. The presence of the crusading bull carried by Diogo Belo destined for Benin is also affirmed in another letter from António Pires to the secretary of state, António Carneiro: see ibid., IV, pp. 109-12. The letter of Duarte Pires is in ibid., I, pp. 369-70.

${ }^{78}$ Ryder, Benin and the Europeans, pp. 69-72.

${ }^{79}$ For example, such a statement critiquing Ozolua's failure to engage sincerely with Christianity was made by João da Barros, who was writing amid further decades of failed missions to Benin: Barros, Da Ásia, década 1, bk 3, ch. 3, p. $27 \mathrm{~b}$.

${ }^{80} \mathrm{~K}$. Lowe, "Representing" Africa: ambassadors and princes from Christian Africa to Renaissance Italy and Portugal, 1402-1608', Transactions of the Royal Historical Society, 6th ser. 17 (2007), pp. 101-28, at pp. 113-14.
} 
these few named examples, the inclusion of other African members in the Portuguese military orders cannot necessarily be discounted. African participation in crusading institutions will undoubtedly increasingly come to light with further study, in addition to a better understanding of the African forms of these institutions, such as the Kongolese Order of Christ, within crusading discourse. The relationship between crusading and Central Africa was multifaceted on each of the social, political, and religious fronts of both Central Africa and Portugal. The two histories of crusading in Central Africa - the European and the African-can therefore be analysed as both distinct and very much interwoven narratives.

\section{III}

The above examples of the role of crusading in Central Africa have sought to highlight the possibility of incorporating more discussion of Africa in crusading studies beyond that of North Africa. Significantly, the crusading material does not cease to exist in subsequent decades and centuries, and equally deserves future study. Moreover, the continuing debate over 'what were the Crusades?' should not limit a broader geographical scope of the discipline's focus. Such a definition remains, and will continue to remain, a moot point. In terms of traditional crusading devices, however, indulgences, banners, vows, and military orders were all used during the Portuguese expansion across Africa and, on occasion, by African rulers themselves. As studies of the diversity of crusading in eastern Europe and the Baltic have shown, limiting discussion of crusading to only those expeditions and engagements which centre on Jerusalem has long been dismissed. The so-called 'later' or post-1291 Crusades feature prominently in current discourse. ${ }^{81}$

However, neither crusading studies nor African studies has looked in detail at Central Africa's role in the historical narrative of crusading. In the case of Kongo, does it at the very least present an example of para- or pseudocrusading? Whatever the case, all three Central African cases of Kongo, Ndongo, and Benin offer unique insights into how crusading ideology underpinned Portuguese expansion, including to the point that it was possible for that ideology to be adopted by African rulers themselves. That said, it is noteworthy that only specific African polities were approached within a veil of crusading. Interaction with lesser rulers appears to have been principally founded on trade, rather than in the search of 'crusading' allies, dependent on their perceived power. This seems to be the case, for example, in the gifting of two aljaravias to the 'king' of Dalé issued by the capitão of São Jorge da Mina, Affonso de Albuquerque, for the opening of a trade route in $1523 .{ }^{82}$ Regional politics was a key factor influencing how each African ruler engaged with the discourse of disseminating the crusading ideal. It is clear that the history

\footnotetext{
${ }^{81}$ The key work on this subject remains N. Housley, The later Crusades, 1274-1580: from Lyons to Alcazar (Oxford, 1992).

${ }^{82}$ ANTT, CC 2/93/75.
} 
of crusading has a much more developed and entwined history in Central Africa than has been hitherto indicated in current scholarship.

The Portuguese continued to view their African endeavours within a crusading narrative. While Benin and Ndongo actively rejected any potential benefits that adopting crusading rhetoric and ideology could have brought, Kongo positioned itself within and alongside a wider Portuguese crusading culture. The adoption of Latin Christianity, specifically based on Portuguese tenets, naturally nurtured crusading concepts in the kingdom. Mwenekongo Afonso was able to adapt such rhetoric and ideologies during the infancy of Kongolese Christianity, thus entwining Kongo with the Latin Christian crusading tradition. It is difficult to say how directly aware the Kongolese were of this crusading heritage, but their own brand of Christianity certainly contained crusading undertones, encapsulated by Afonso's vision of the cross and Santiago Matamoros on the eve of the battle against his brother which confirmed him as the mwenekongo. Most importantly, imported crusading ideologies served to situate Afonso's rule over his pagan brother within a veil of divine favour, thus underpinning his authority. Afonso's long reign enabled such notions of crusading to develop independently from Portuguese influence and into their own Kongolese forms, most clearly portrayed by the Kongolese Order of Christ and the 'Africanization' of Santiago by 1622 at the battle of Mbumbi. The adoption of crusading ideology also aided in prospering Kongo's increasingly close relationship to the papacy, particularly when the papacy could offer protection from Portuguese encroachment into Kongolese affairs. Most of all, Kongo's adoption of crusading discourse was good for both internal and external politics.

Funding statement. This research was graciously funded by a Leverhulme Early Career Fellowship.

Cite this article: Simmons A (2021). The African Adoption of the Portuguese Crusade during the Fifteenth and Sixteenth Centuries. The Historical Journal 1-20. https://doi.org/10.1017/ S0018246X21000510 